\title{
Designing and Analysis of Lightweight InGaN/GaN PV Cell
}

\author{
https://doi.org/10.3991/ijes.v8.i2.14809 \\ Shadia Chowdhury \\ Southeast University, Dhaka, Bangladesh \\ Md Moidul Islam ${ }^{(凶)}$, Md. Mostafizur Rahman, \\ Mission Kumar Debnath, Samera Hossain \\ American International University-Bangladesh (AIUB), Dhaka, Bangladesh \\ moidshozib@gmail. com
}

\begin{abstract}
This paper is an effort to analyze the performance of $\mathrm{InGaN} / \mathrm{GaN}$ solar cell. InGaN/GaN solar cell contains $p$ and n-type layer of $\mathrm{GaN}$ and intrinsic layer of InGaN. The proposed structure of solar cell also contains front TCO, back TCO and back reflector layers. This paper represents the mechanism of designing and analysis of InGaN/GaN solar cell. Performance of the designed solar cell was checked based on electric field, current density and electric potential generated in the designed cell. J-V curve is the most important factor to analyze the performance of the solar cell. Power conversion efficiency (PCE) and fill factors have been calculated from this graph. According to the analysis of the simulation results PCE $(\eta)$ of the designed solar cell is $12.91 \%$ with $J_{\text {sc }}$ of $19.3 \mathrm{~mA} / \mathrm{cm}^{2}$ and $V_{\text {oc }}$ of $0.78 \mathrm{~V}$. At the end, this research work is about designing successfully with an efficient InGaN/GaN solar cell for further use in solar applications.
\end{abstract}

Keywords - $\operatorname{In}_{\mathrm{x}} \mathrm{Ga}_{1-\mathrm{x}} \mathrm{N}, \mathrm{GaN}, \mathrm{InGaN} / \mathrm{GaN}$, Electric Field, Electric Potential, Current Density, J-V curve, COMSOL Multiphysics.

\section{Introduction}

Throughout the world, power generation and implementation are one of the big challenges. History says from the beginning, everywhere has countless struggles for power or electricity generation. Solar system power generation is now the new form of power, which not only dominates world politics, but also directly supports the grass-root activity of the society and has the potential to uplift human standards of living. However, this era of new power does not come without a new set of challenges - degradation of the environment, long-term sustainability, and national security issues. Hence, our struggle for power persists as we explore alternate ways to secure our future [1].

Nowadays Renewable energy vastly expanded throughout the world because of its environmentally friendly system. The development of new technologies is increasing 
by researchers, governments, consumers, business sectors because of the focus on Renewable energy for generating power and electricity. Though most of the electricity generates from different kind of fossil fuels like as coal, oil and natural gas, natural resources which are limited because they collect from the earth's surface (most of the fossil fuel) [2]. Another important fact is the price which will be rises day after day. Therefore, Renewable energy sources like solar, geothermal, biomass, hydroelectric and wind power generation have come out as potential alternative in concerns. The main concern of ours is to use solar system of unlimited Renewable energy resources as a power/energy source. By designing and analysis of the PV Solar cell by using InGaN/GaN which can be the part of Renewable energy resources which improvement, efficiency growing rapidly throughout the world as a source of electricity.

Indium gallium nitride ( $\mathrm{InGaN})$ is a semiconductor material made of a mix ofgallium nitride $(\mathrm{GaN})$ andindium nitride $(\mathrm{InN})$. It is a ternary group III/group Vdirect bandgap semiconductor. The ability to perform bandgap engineering with InGaN over a range that provides a good spectral match to sunlight, makes InGaN suitable for solar photovoltaic cells [1][2]. It is possible to grow multiple layers with different band gaps, as the material is relatively insensitive to defects introduced by a lattice mismatch between the layers [3].

The significant photo response was obtained from experimental InGaN singlejunction devices [4][5]. In addition to controlling the optical properties which results in band gap engineering, photovoltaic device performance can be improved by engineering the microstructure of the material to increase the optical path length and provide light trapping [6]. Growing nano-columns on the device can further result in resonant interaction with light [7].

This paper is organized as follows: Section II presents a short review on InGaN/GaN solar cell. Section III describes the experimental design, materials, and parameters of the designed cell. Section IV represents the discussion and analysis of the simulated results of the designed cell. Then with Section V this paper ends with a conclusion.

\section{Review on InGaN/GaN Solar Cell}

As a tunable band gap material among the III-nitride materials, InGaN has been attracting increasing attention in the field of solar cells. This can be largely attributed to its wide and continuous band gap coverage $(0.69-3.4 \mathrm{eV})$ covering the span of the whole solar spectrum, which can be adjusted simply by changing the indium (In) content in the alloy [35]-[37]. Besides, InGaN has other advantages in photovoltaic cells application, such as high absorption coefficients of $\sim 105 \mathrm{~cm}-1$ near the band edge [38], superior radiation resistance compared to other conventional photovoltaic materials and extensive technology development in high-performance light-emitting diodes [35][39]. The increase of the in content is beneficial to extending the absorption range and enhancing the effective light absorption for the InGaN based solar cell. It has been observed that the increase for the in composition often accompanies by the phase separation in the process of growth, which will lead to the quality deterioration 
of the InGaN film. Furthermore, this deterioration will become more serious as the thickness of the InGaN layer is increased [41]. The reasons are mainly because InGaN is typically grown on GaN layers and the lattice mismatch strain limits the indium composition and layer thickness. Additionally, to incorporate sufficient indium, InGaN growth is performed at low growth temperatures, resulting in increased incorporation of impurities or other point and defect related non-radioactive recombination centers [42].

In addition, InGaN/GaN can be viewed as an ideal candidate PV material for both this potential band gap engineering and microstructural engineering in nano-columns that offer optical enhancement. InGaN is an extremely versatile potential PV material that enables several known photovoltaic device configurations and multi-junctions. This potential is driving immense scientific interest in the material system.

The FF is defined as the ratio of the maximum power from the solar cell to the product of open circuit voltage $\left(\mathrm{V}_{\mathrm{oc}}\right)$ and short circuit current $\left(\mathrm{I}_{\mathrm{sc}}\right)$. FF is a measure of the "squareness" of the IV curve, a solar cell with a higher voltage has a larger possible FF.

$$
\text { Fill Factor, } \mathrm{FF}=\frac{V_{o c}-\ln \left(V_{o c}+0.72\right)}{V_{o c}+1}
$$

Where $\mathrm{V}_{\mathrm{oc}}$ is defined as a "normalized $\mathrm{V}_{\mathrm{oc}}$ ":

$$
\text { Normalized } \mathrm{V}_{\mathrm{oc}}=\frac{q}{n K T} \mathrm{~V}_{\mathrm{oc}}
$$

The efficiency of a solar cell is determined as the fraction of incident power which is converted to electricity and is defined as:

$$
\begin{gathered}
P_{\max }=V_{o c} \times I_{s c} \times \text { Fill Factor } \\
\text { Efficiency }=\frac{P_{\max }}{P_{\text {in }}}
\end{gathered}
$$

Where, $V_{o c}$ is the open-circuit voltage, $I_{s c}$ is the short-circuit current, FF is the fill factor and $\eta$ is the efficiency.

\section{Experimental Design}

This paper presents effort to design $\mathrm{In}_{\mathrm{x}} \mathrm{Ga}_{1-\mathrm{x}} \mathrm{N} / \mathrm{GaN}$ PV cell using COMSOL Multiphysics. COMSOL Multiphysics has been used because of its unique flexibility. This simulation tool provides partial differential equations and one can simulate physical processes. Designed solar cell contains transparent glass layer, front TCO, p-type layer, intrinsic layer, n-type layer, back TCO and back reflector. Total thickness of the designed solar cell is $1.45 \mu \mathrm{m}$. Table 1 show the materials used in different layers and thickness of the layer. 


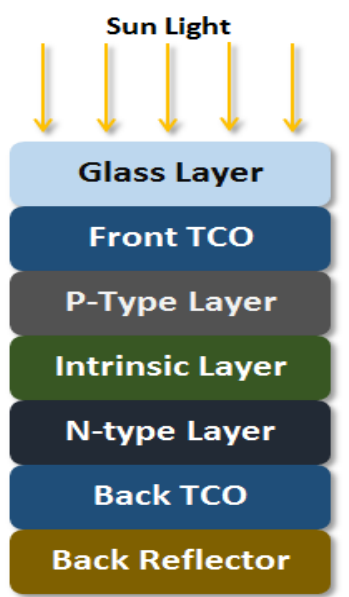

Fig. 1. Schematic diagram of the designed $\mathrm{InGaN} / \mathrm{GaN}$ PV cell.

Table 1. Name of the layers, materials \& thickness of the layers.

\begin{tabular}{|l|l|c|}
\hline \multicolumn{1}{|c|}{ Layer } & \multicolumn{1}{c|}{ Material Used } & Thickness \\
\hline Glass & Glass & $500 \mathrm{~nm}$ \\
\hline Front TCO & $\mathrm{SnO}_{2}: \mathrm{F}$ & $200 \mathrm{~nm}$ \\
\hline p-type layer & $\mathrm{GaN}$ & $50 \mathrm{~nm}$ \\
\hline Intrinsic layer & $\mathrm{In}_{\mathrm{x}} \mathrm{Ga}_{1-\mathrm{x}} \mathrm{N}$ & $200 \mathrm{~nm}$ \\
\hline n-type layer & $\mathrm{GaN}$ & $100 \mathrm{~nm}$ \\
\hline Back TCO & $\mathrm{ZnO}: \mathrm{Al}$ & $200 \mathrm{~nm}$ \\
\hline Back reflector & $\mathrm{Ag}$ & $200 \mathrm{~nm}$ \\
\hline
\end{tabular}

\section{Analysis of Simulated Results}

COMSOL Multiphysics simulator was used to design and analyze the performance of designed the solar cell. In the simulator different physics including Electromagnetic waves, Electrostatics and transport of diluted species were used. For simulation wavelength range of $380 \mathrm{~nm}$ to $750 \mathrm{~nm}$ was defined to check the performance for different wavelength. This is the range for visible spectrum. According to the solar spectrum for different wavelength within this range highest amount of solar radiation enters the atmosphere. But the main concentration was at $530 \mathrm{~nm}$.

When sunrays enter the top glass layer, photons are absorbed by the front TCO and it generates electric field in the top glass and front TCO layer. Glass layer is used as a protective layer for the rest of the layers. Then the generated electric field goes downward through p-type layer. In a p-i-n solar cell the surface charge density is greater in n-type layer. As the majority carriers of n-type layer are electrons and the majority carriers of p-type layer are holes. So, when photons are absorbed by front TCO and electric fields or energy goes downward. It will excite the electrons of ntype layer. So, electrons will flow from n-type layer towards p-type layer. So, there will current flow from p-type layer to n-type layer. And the back-reflector layer is 
used so that the absorbed photons can be back reflected. Fig. 2 shows electric field generated in the top glass layer and front TCO layer.

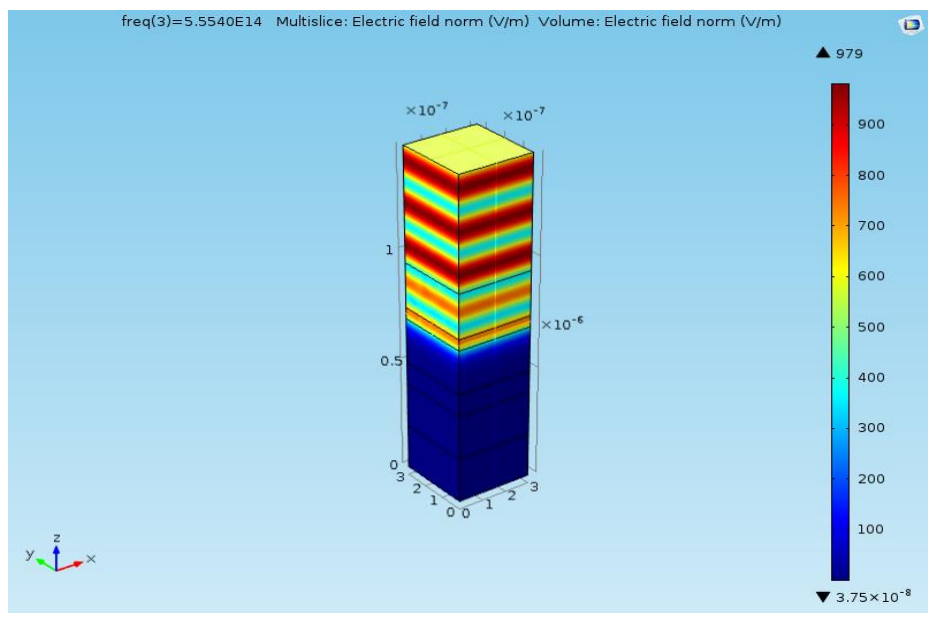

Fig. 2. Electric field generated in the glass layer and front TCO layer after photon absorption.

Then the electric fields will pass downwards. Fig. 3 shows the electric field in the glass is absorbed by TCO. And Fig. 4 shows the graphical representation for different wavelengths. From the graph we can see that the value of electric field will increase when arc length is $600 \mathrm{~nm}$. Here arc length means the thickness of the solar cell from the bottom.

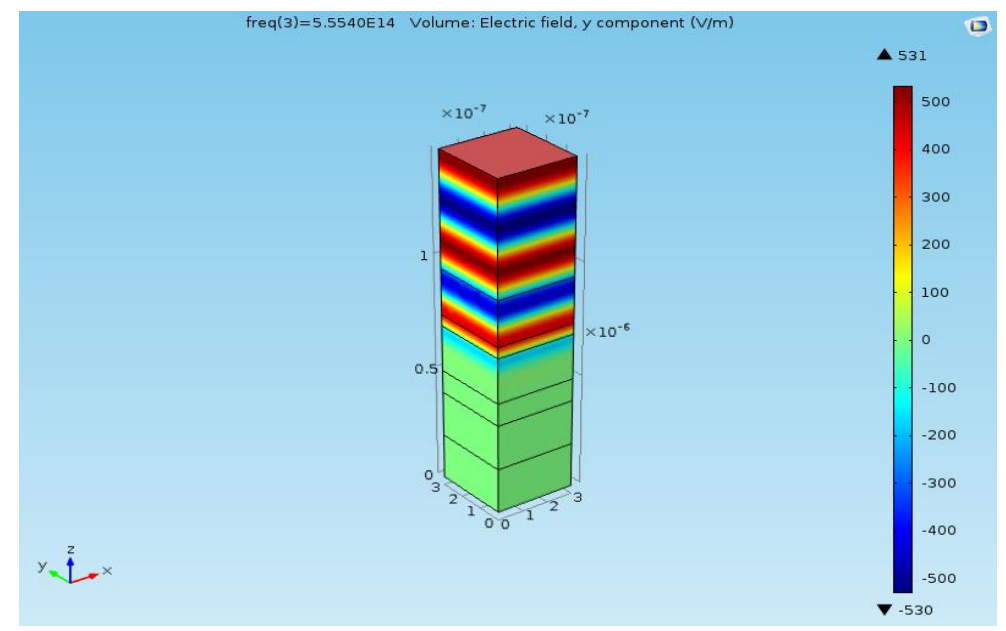

Fig. 3. Electric field absorbed in TCO layer of designed solar cell. 


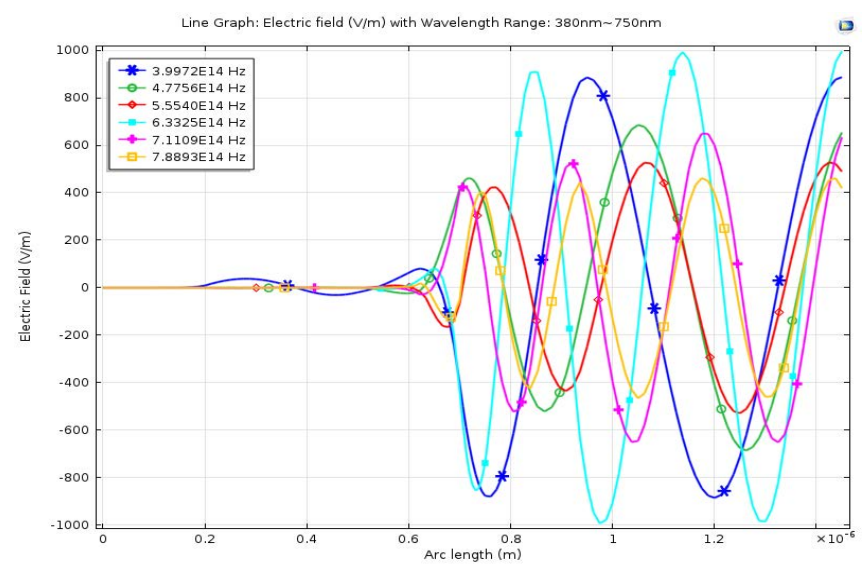

Fig. 4. Graph of electric field versus arc length.

Electrons flow from n-type layer to p-type layer. So current density will be higher from $600 \mathrm{~nm}$. Fig. 5 shows graphical representation of current density versus arc length. From the figure current density is higher after arc length of $600 \mathrm{~nm}$. Because $\mathrm{n}$-type layer end at $600 \mathrm{~nm}$ and p-type layer is at arc length of $800 \mathrm{~nm}$. And anode are p-type layer and cathode are n-type layer.

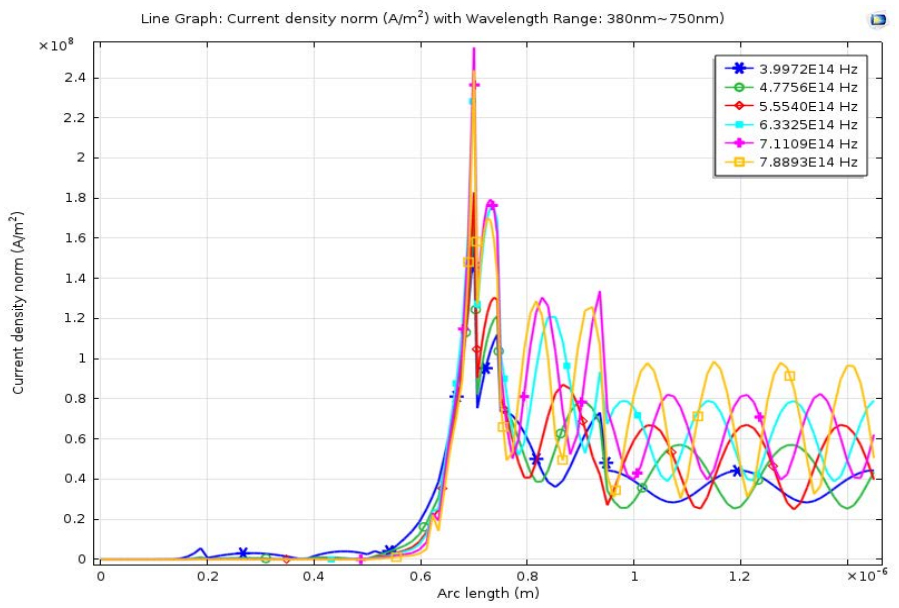

Fig. 5. Graph of current density versus arc length.

The generation rate gives the number of electrons generated at each point in the device due to the absorption of photons. Fig. 6 shows the graph of g-generation rate in the designed solar cell for different wavelengths. G generation rate graph start increasing after arc length of $600 \mathrm{~nm}$. So, g-generation rate is high from arc length of $600-650 \mathrm{~nm}$ for all the wavelengths. Then it is at minimum value again. 


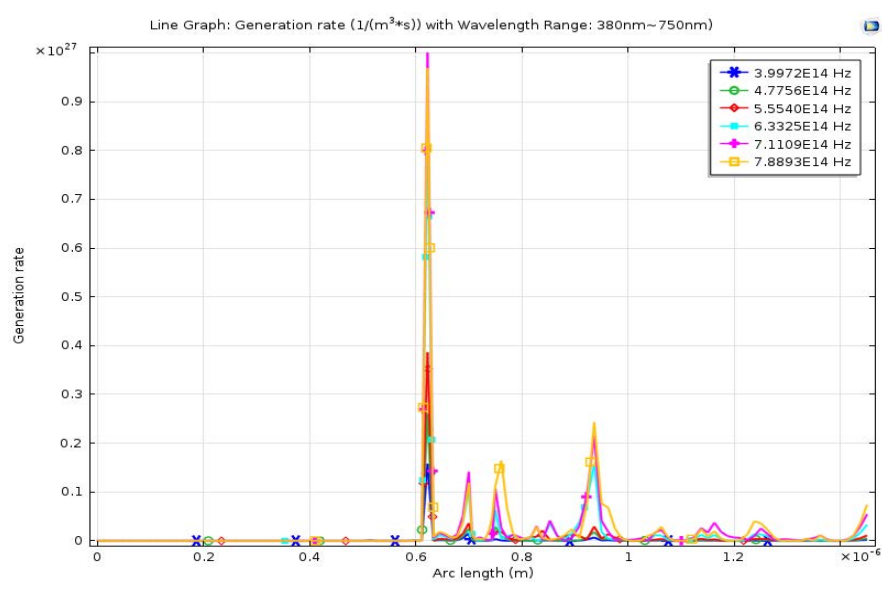

Fig. 6. Graph of generation rate versus arc length.

Solar cells generate electric energy. Electrons flow from n-type layer to p- type layer. That means electric potentials will be lower in p-type layer and electric potential will be higher at n-type layer. For this reason, electrons will jump from n-type layer to p-type layer. So current will flow in the opposite direction. Fig. 7 shows electric potential in the designed solar cell at thermal equilibrium. According to the figure electric potential is higher is n-type layer.

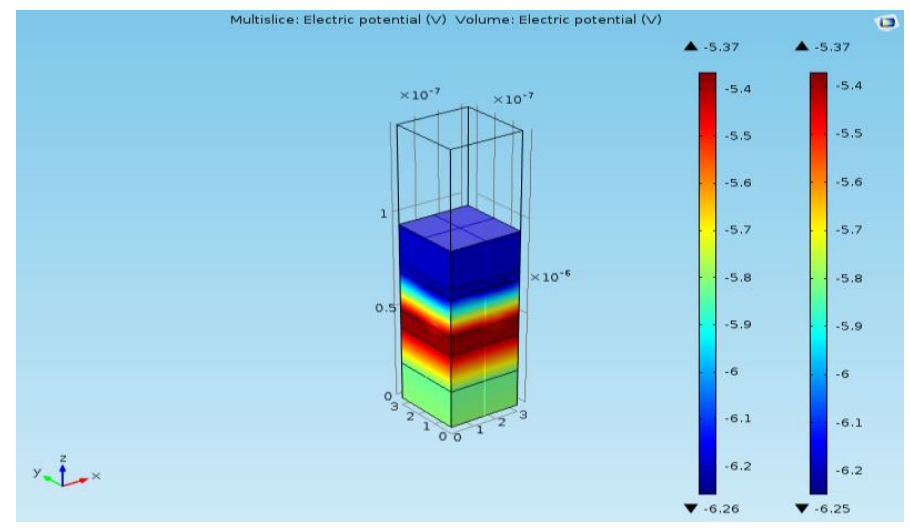

Fig. 7. Electric potential generated in the solar cell.

Electric potential generated in the designed solar cell were analyzed by using voltage sweep which means changing the voltage. And this time electric potential was analyzed at non-thermal equilibrium. Fig. 8 shows electric potential for $V_{d}=0.42 \mathrm{~V}$ in the solar cell. This voltage $\left(\mathrm{V}_{\mathrm{d}}\right)$ value can be varied. This is the range of voltage from $0 \mathrm{~V}$ to $2.5 \mathrm{~V}$. According to the figure electric potential is higher in n-type layer and lower in p-type layer. Thus, electrons will flow from n-type layer to p-type layer. 


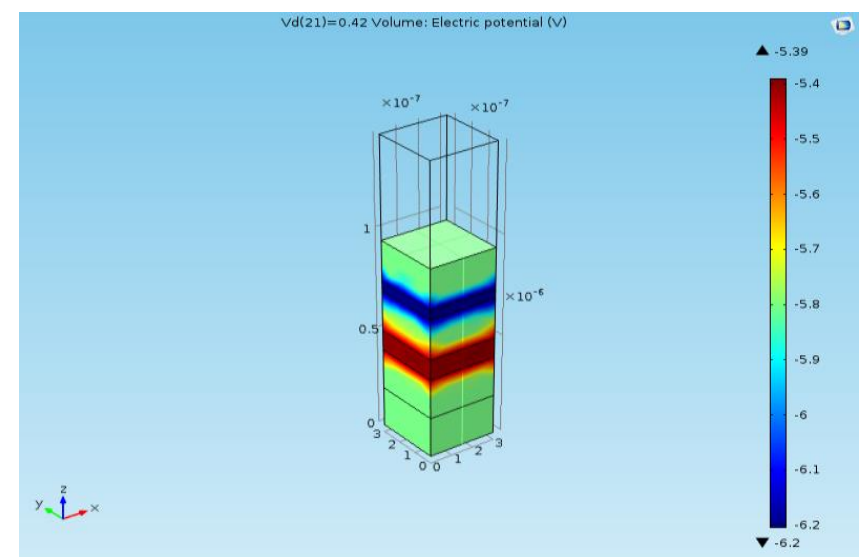

Fig. 8. Electric potential generated in designed solar cell at non-thermal equilibrium.

$\mathrm{J}-\mathrm{V}$ curve is the most important result to analyze the performance of a solar cell. Fig. 9 shows the J-V curve of the designed solar cell.

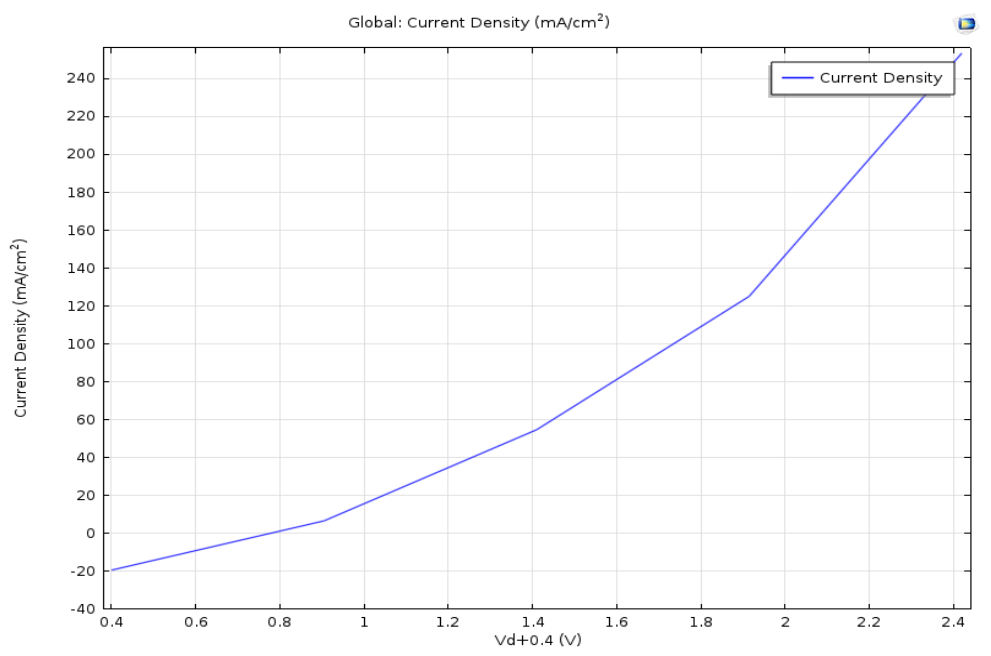

Fig. 9. Graph of current density versus Voltage

According to the figure, open circuit voltage $\left(\mathrm{V}_{\mathrm{oc}}\right)=0.78 \mathrm{~V}$, short circuit current density $\left(\mathrm{J}_{\mathrm{sc}}\right)=19.3 \mathrm{~mA} / \mathrm{cm} 2$. The fill factor and efficiency were calculated using eqn. (1) and (4).

Fill factor $=85.78 \%$

Efficiency $=12.91 \%$ 


\section{Conclusion}

Solar energy is one of the alternative ways. There is a huge demand for solar cells as alternative electricity source for nowadays. But the efficiency is not up to the mark. Thus, researchers are trying to increase the efficiency. There is a huge demand for $\mathrm{InGaN} / \mathrm{GaN}$ solar cells. But their efficiency is not up to the mark. This work presents effort to explain the mechanism of this type of solar cell. The efficiency can be increased by changing the thickness of intrinsic layer. This paper represents designing and performance analysis of this type of solar cell in COMSOL Multiphysics. According to the analysis of the simulated results efficiency of the designed solar cell was $12.91 \%$ with fill factor of $85.78 \%$. At the end this was a success to design an efficient InGaN/GaN pin type solar cell for further use in solar applications.

\section{$6 \quad$ References}

[1] McLaughlin, D.V.P.; Pearce, J.M. (2013). "Progress in Indium Gallium Nitride Materials for Solar Photovoltaic Energy Conversion". Metallurgical and Materials Transactions A. 44(4): 1947-1954. https://doi.org/10.1007/s11661-013-1622-1

[2] Bhuiyan, A.; Sugita, K.; Hashimoto, A.; Yamamoto, A. (2012). "InGaN Solar Cells: Present State of the Art and Important Challenges". IEEE Journal of Photovoltaics. 2 (3): 276293. https://doi.org/10.1109/jphotov.2012.2193384

[3] "A nearly perfect solar cell, part 2", Www2.lbl.gov, 2016. [Online]. Available: http://www2.lbl.gov/Science-Articles/Archive/MSD-perfect-solar-cell-2.html. [Accessed: 02- Dec- 2016].

[4] Sun, X.; et al. (2008). "Photoelectric characteristics of metal/InGaN/GaN heterojunction structure". J. Phys. D. 41: 165108. https://doi.org/10.1088/0022-3727/41/16/165108.

[5] Dirk V. P. McLaughlin; J.M. Pearce (2012). "Analytical Model for the Optical Functions of Indium Gallium Nitride with Application to Thin Film Solar Photovoltaic Cells". Materials Science and Engineering: B. 177: 239-244. arXiv:1201.2911. https://doi.org/10.1016/j.mseb.2011.12.008

[6] Cao, L.; White, J. S.; Park, J. S.; Schuller, J. A.; Clemens, B. M.; Brongersma, M. L. (2009). "Engineering light absorption in semiconductor nanowire devices". Nature Materials. 8 (8): 643-647. https://doi.org/10.1038/nmat2477 .

[7] S. Keating; M.G. Urquhart; D.V.P. McLaughlin; J.M. Pearce (2011). "Effects of Substrate Temperature on Indium Gallium Nitride Nanocolumn Crystal Growth".Crystal Growth \& Design. 11 (2): 565-568. https://doi.org/10.1021/cg101450n .

[8] R. Alley et al., "Climate Change 2007: The Physical Science Basis Summary for Policymakers," Contribution of Working Group I to the Fourth Assessment Report of the Intergovernmental Panel on Climate Change, Paris, February 2007. https://doi.org/10.1017/c bo9781107415324.006

[9] "Global Warming, the Ozone Layer, and Acid Rain," an original document written by the West Wales ECO Center, 2006 (URL: http://www.ecocentre.org.uk/global-warming.html).

[10] Solar Installers - Top 6 Things to Know Before Choosing. (n.d.). Retrieved March 9, 2015, from http://solarenergy.com/solar-resources/solar-installers-top-6-things-to-knowbefore-choosing.

[11] History of Solar Energy. (.n.d). Retrieved February 19,2015, from http://exploringgreentechnology.com/solar-energy/history-of-solar-energy/ 
[12] Z. Shuti Li, "Enhanced performance of $\mathrm{InGaN} / \mathrm{GaN}$ based solar cells with an In $0.05 \mathrm{Ga} 0.95 \mathrm{~N}$ ultra-thin inserting layer between $\mathrm{GaN}$ barrier and $\mathrm{In} 0.2 \mathrm{Ga} 0.8 \mathrm{~N}$ well", 2016. [Online]. Available: https://doi.org/10.1364/oe.21.007118

[13] https://www.osapublishing.org/view article.cfm?gotourl=https $\% 3 \mathrm{~A} \% 2 \mathrm{~F} \% 2 \mathrm{Fwww} \% 2 \mathrm{E}$ osa publishing\%2Eorg\%2FDirectPDFAccess\%2F969E3FBC-972D-FFA3-EE10A51BDC43A 3CF 250824\%2Foe-21-6-7118\%2Epdf $\% 3$ Fda $\% 3$ D1 $\% 26$ id $\% 3$ D $250824 \% 26$ seq $\% 3$ D0 $\% 26$ mobile\%3Dno\&org=. [Accessed: 29- Mar- 2016].,

[14] J., Ballif, C. (2010). Properties of interfaces in amorphous/crystalline silicon heterojunctions. Physica Status Solidi (a), 207(3), 651-656. doi:10.1002/pssa.200982845

[15] De Wolf, S., Demaurex, B., Descoeudres, A., \& Ballif, C. (2011). Very fast light-induced degradation of a -Si:H/ c -Si(100) interfaces. Physical Review B, 83(23), 233301. https:// doi.org/10.1103/physrevb.83.233301

[16] Science and technology: Sunny uplands | The Economist. (n.d.). Retrieved April 4, 2015, from http://www.economist.com/news/21566414-alternative-energy-will-no-longer-be-alte rnative-sunny-uplands.

[17] Price Quotes_EnergyTrend PV. (n.d.). Retrieved January 29, 2015, from http://pv.energytrend.com/pricequotes.html.

[18] Amorphous silicon solar cells: Solar Facts and Advice. (n.d.). Retrieved April 5, 2015, from http://www.solar-facts-and-advice.com/amorphous-silicon.html

[19] Hegedus, S. (2005). Amorphous Silicon Solar Cells Thin Film Amorphous Silicon Solar Cells Solar Cell Design and Processing. https://doi.org/10.1007/978-1-4899-0418-8 10

[20] Jansen, K., Kadam, S., \& Groelinger, J. (2006). The Advantages of Amorphous Silicon Photovoltaic Modules in Grid-Tied Systems. In 2006 IEEE 4th World Conference on Photovoltaic Energy Conference (Vol. 2, pp. 2363-2366). IEEE. https://doi.org/10.1109 /wcpec.2006.279666.

[21] E. D. Jackson, "Areas for Improvement of the Semiconductor Solar Energy Conductor," Transactions of the Conference on Use of Solar Energy - The Scientific Base, vol. 5, p. 122,1955

[22] E. D. Jackson, US Patent 2,949,498, August 16, 1960.

[23] "PVEducation", Pveducation.org, 2016. [Online]. Available: http://pveducation.org/. [Accessed: 04- Nov- 2016].

[24] Types of eligible Solar PV technologies | microFIT - Independent Electricity System Operator. (n.d.). Retrieved February 22, 2015, from http://microfit.powerauthority.on. ca/types-eligible-solar-pv-technologies

[25] How Photovoltaic Cells Generate Electricity. (n.d.). Retrieved May 5, 2015, from https://www.imagesco.com/articles/photovoltaic/photovoltaic-pg4.html

[26] Deng, X., \& Schiff, E. (2003). Amorphous silicon based solar cells. Handbook of Photovoltaic Science and Engineering. doi:10.1002/0470014008.ch12

[27] "Multiphysics Simulation Software - Platform for Physics-Based Modeling." [Online]. Available: http://www.comsol.com/comsol-multiphysics. [Accessed: 11-Nov-2016].

[28] “COMSOL Multiphysics ${ }^{\circledR}$ Product Suite.” [Online]. Available: http://www.comsol. com/products. [Accessed: 12-Nov-2016].

[29] "COMSOL Introduction | Humusoft". Humusoft.cz. N.p., 2016. Web. 20 Nov. 2016.

[30] "File: Solar Spectrum.png - Wikimedia Commons", Commons.wikimedia.org, 2016. [Online]. Available: https://commons.wikimedia.org/wiki/File:Solar Spectrum.png. [Accessed: 20- Nov- 2016]. https://doi.org/10.5860/choice.46-5933

[31] "Thin-Film Solar Technology - Residential Solar 101", Residential Solar 101, 2016. [Online]. Available: http://www.residentialsolar101.org/thin-film-solar-technology/. [Accessed: 15- Dec- 2016]. https://doi.org/10.1016/b978-0-08-034315-0.50024-0 
[32] S. Dong, K. Chen, G. Chen and X. Chen, "Solar Cells with InGaN/GaN and InP/InGaAsP and InGaP/GaAs Multiple Quantum Wells", 2016. https://doi.org/10.5772/58899

[33] "PVEducation", Pveducation.org, 2016. [Online]. Available: http://pveducation.org/. [Accessed: 04- Nov- 2016].

[34] Green, M.A. (1981) Solar cell fill factors: General graph and empirical expressions. Solid State Electronics, 24, 788-789. https://doi.org/10.1016/0038-1101(81)90062-9.

[35] J. Wuet al., "Superior radiation resistance of In1-xGaX N alloys: Full- solar-spectrum photovoltaic material system," J. Appl. Phys., vol. 94, no. 10, pp. 6477-6482, Nov. 2003. https://doi.org/10.1063/1.1618353

[36] J. Wu, "When group-III nitrides go infrared: New properties and perspectives," J. Appl. Phys., vol. 106, p. 011101, Jul. 2009.

[37] Yamamoto, M. R. Islam, T.-T. Kang, and A. Hashimoto, "Recent advances in InN-based solar cells: Status and challenges in InGaN and InAlN solar cells," Phys. Status Solidi C, vol. 7, no. 5, pp. 1309-1316, Mar. 2010. https://doi.org/10.1002/pssc.200983106

[38] David and M. J. Grundmann, "Influence of polarization fields on carrier lifetime and recombination rates in InGaN-based light-emitting diodes," Appl. Phys. Lett., vol. 97, no. 3, p. 033501, Jul. 2010. https://doi.org/10.1063/1.3462916

[39] Z. Bi, J. Zhang, L. Lv, and Y. Hao, "The effect of 3-MeV proton irradiation on the performance of InGaN/GaN MQWs solar cells," IEEE Photon. Technol. Lett., vol. 26, no. 15, pp. 1492-1494, Aug. 1, 2014. https://doi.org/10.1109/lpt.2014.2327072

[40] Bhuiyan, K. Sugita, A. Hashimoto, and A. Yamamoto, "InGaN solar cells: Present state of the art and important challenges," IEEE J. Photovolt., vol. 2, no. 3, pp. 276-293, Jul. 2012. https://doi.org/10.1109/jphotov.2012.2193384

[41] F.A.Ponce et al., "Microstructure and electronic properties of InGaN alloys,"Phys. Status Solidi B, vol. 240, no. 2, pp. 273-284, Nov. 2003

[42] X. H. Wu et al., "Structural origin of V-defects and correlation with localized excitonic centers in InGaN/GaN multiple quantum wells," Appl. Phys. Lett., vol. 72, no. 6, pp. 692694, Feb. 1998. https://doi.org/10.1063/1.120844

\section{Authors}

Shadia Chowdhury received the B.Sc. degree in electronics and telecommunication engineering from Southeast University, Bangladesh in 2015. Her fields of interest are solar cell designing, image processing, photonics \& spectroscopy etc. Currently she is studying Master in Photonics at FSU Jena. Also, she has worked on preparation and characterization of organic solar cells. Now she is working on FMCW distance measurement with a self-heterodyne technique using a DFB laser. chowdhuryshadia@yahoo.com

Md. Moidul Islam received the B.Sc. degree in electrical and electronic engineering from American International University-Bangladesh in 2014 with an excellent academic background. His fields of interest are solar cell designing, antenna designing, materials science, photonics, micro \& nanoelectronics. Currently he is studying Master in Photonics at FSU Jena. He is working on preparation and characterization of organic solar cells.

Md. Mostafizur Rahman received the B.Sc. degree in electrical and electronic engineering from American International University-Bangladesh in 2014. His fields 
of interest are renewable energy, antenna designing, wireless communications \& nanoelectronics.

Mission Kumar Debnath received the B.Sc. degree in electrical and electronic engineering from American International University-Bangladesh in 2016. His fields of interest are solar cell designing, image processing technology.

Samera Hossain received the B.Sc. degree in electrical and electronic engineering from American International University-Bangladesh in 2014. Her fields of interest are solar cell designing \& nanoelectronics.

Article submitted 2020-04-13. Resubmitted 2020-05-02. Final acceptance 2020-05-04. Final version published as submitted by the authors. 